\section{TÜRKIYYE'DE ÜÇÜZ AÇIK İLE EKONOMIK BÜYÜME ARASINDAKİ İLIŞKİ}

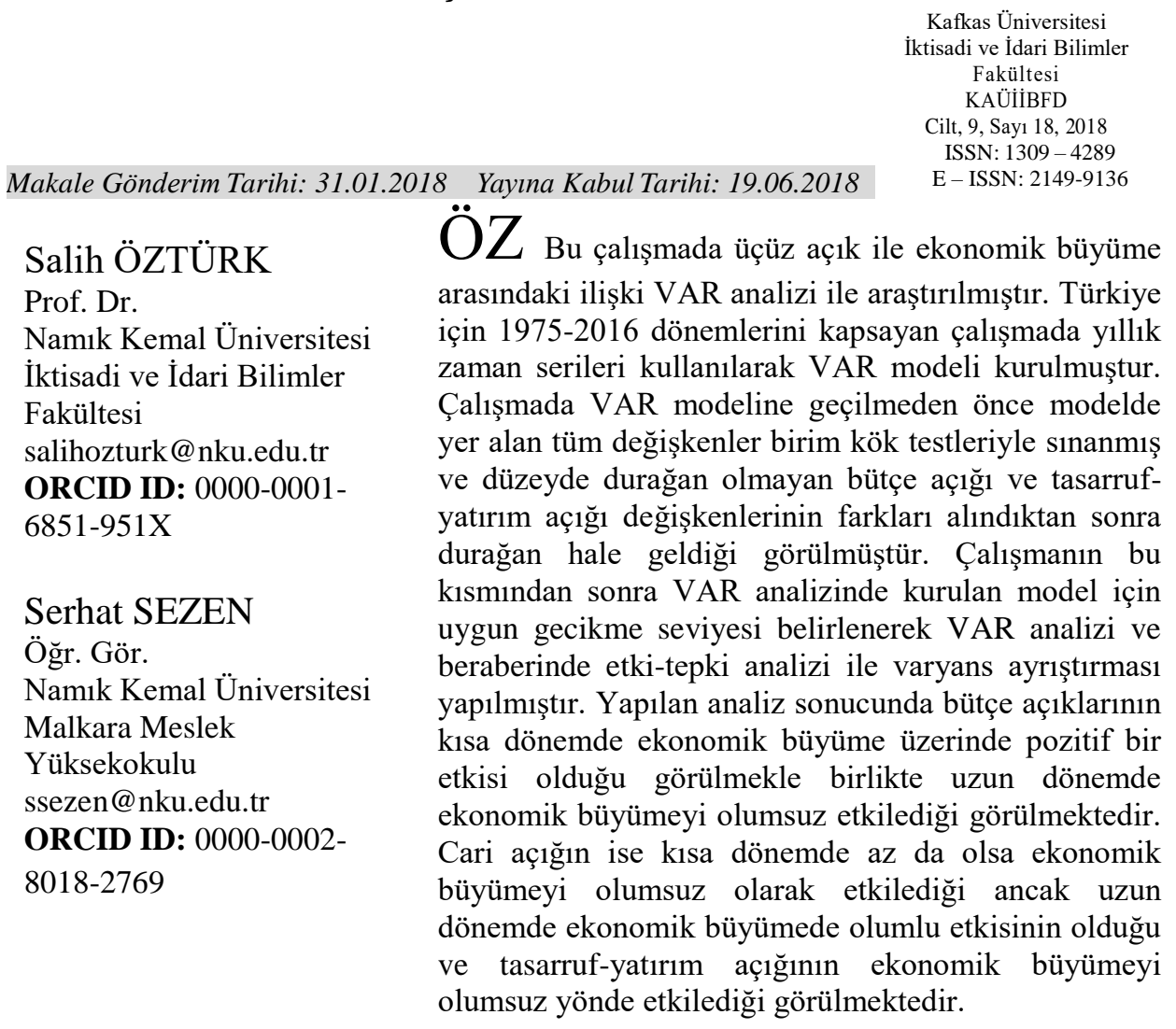

Anahtar kelimeler: Ekonomik büyüme, üçüz açık, VAR analizi

JEL kodları: E21, O47, C22

Alanı: İktisat

Türü: Araştırma

DOI:10.9775/kauiibfd.2018.022

Atıfta bulunmak için: Öztürk, S. \& Sezen, Ş. (2018). Türkiye'de üçüz açık ile ekonomik büyüme arasındaki ilişki. KAÜIIIBFD, 9(18), 501-522. 


\title{
THE RELATIONSHIP BETWEEN TRIPLE DEFICIT AND ECONOMIC GROWTH IN TURKEY
}

\author{
Kafkas Üniversity \\ Economics and Administrative \\ Sciences Faculty \\ KAUJEASF \\ Article Submission Date: 31.01.2018 Accepted Date: 19.06.2018 \\ Vol. 9, Issue 18, 2018 \\ ISSN: $1309-4289$ \\ E-ISSN: 2149-9136
}

\section{Salih ÖZTÜRK \\ Prof. Dr. \\ Namık Kemal University \\ Faculty of Economics and \\ Administrative Sciences \\ salihozturk@nku.edu.tr \\ ORCID ID: 0000-0001- 6851-951X}

\section{Serhat SEZEN}

Lecturer

Namık Kemal University

Malkara Vocational Junior

College

ssezen@nku.edu.tr

ORCID ID: 0000-0002-

8018-2769

\begin{abstract}
In this paper, the relationship between triple deficit and economic growth was investigated by VAR analysis. VAR model using annual time series covering the 1975-2016 study period was established for Turkey. Before the VAR model was introduced, all variables in the model were tested with the unit root tests and it was observed that the nonstationary budget deficit and savings-investment deficit variables became stable after taking the differences. After this part of the paper, the appropriate delay level was determined for the model established in the VAR analysis and variance decomposition was performed by VAR analysis and accompanying effect-response analysis. As a result of the analysis, it is seen that budget deficits have a positive effect on economic growth in the short term, but it affects economic growth in long term negatively. The current account deficit negatively impacts economic growth in the short term but has a positive impact on economic growth in the long run and the savings-investment deficit has a negative effect on economic growth.
\end{abstract}

Keywords: Economic growth, trible deficit, VAR analysis

JEL codes: E21, O47, C22

Scope: Economics

Type: Research

Cite this Paper: Öztürk, S. \& Sezen, Ş. (2018). The relationship between triple deficit and economic growth in Turkey. KAUJEASF, 9(18), 501-522. 


\section{GİRIS}

Her ülke kalkınabilmek için gereken sermayeyi kendi tasarruflarıyla sağlayamaz. Gelişmekte olan ülkelerde ekonomik gelişmeyi engelleyen nedenlerin en önemlileri arasında milli gelir seviyelerinin gerekenin çok altında olması, yurtiçindeki tasarrufların yetersiz kalması ve zorunlu sermaye mallarının ithalatı için gerekli ödemelerden dolayı ortaya çıkan dış ticaret açıı̆ıdır. Dış ticaret açığını kapsayan cari açı, özellikle yatırımların finansmanında gerekli olan yurtiçindeki tasarrufların yetersizliği ve devletin elde ettiği vergi gelirlerinden daha fazla yaptığı harcamalar sonucu ortaya çıkan bütçe açıkları politika yapıcıların kararlarında önemli göstergeler olarak kullanılmaktadır (Tülümce, 2013, s. 98). Tüm bu ifade edilen nedenlerden dolayı bir ülkede makroekonomik dengenin sağlanabilmesi için bütçe, cari işlemler ve tasarruf-yatırım dengelerinin sağlanması gerekmektedir. Bu üç önemli makro ekonomik değişkenin birlikte dengeye gelmesini sağlamaya çalışmak gelişmiş ve gelişmekte olan ülkelerin tamamı açısından da ciddi bir sorun oluşturmaktadır (Şen, Şentürk, Sancar \& Akbaş, 2014, s. 81-82).

1980'li yılların başından itibaren küreselleşmenin hızlanmasıyla birlikte ABD başta olmak üzere birçok ülkede büyük ölçekli bütçe açıkları ve cari işlemler açığı ortaya çıkmıştır. Bu açıkların birlikte görülmesi bu değişkenler arasında bir ilişkinin var olup olmağ 1 sorusunu gündeme getirmiş ve sonrasında bu ilişkiye ekonomi literatüründe, "İkiz Açık Hipotezi" denmiştir (Marinheiro, 2008, s. 1042). İkiz açık hipoteziyle ilgili literatürde iki farklı görüş ortaya çıkmıştır. İlk görüş, ikiz açık hipotezinin geçerli olduğunu savunmakta olan geleneksel yaklaşım diye adlandırılan Keynesyen görüştür. Bu görüş, bütçe açığı ile cari açığın aralarında kuvvetli bir ilişki olduğunu ifade etmektedir. İkinci görüşe göre ise, Ricardo-Barro Denklik Hipotezi kapsamında bütçe açı̆̆ 1 ile cari açığın aralarında bir ilişkinin olmadığını ifade etmektedir (Berke, Temiz \& Karakurt, 2015, s. 68).

Üçüz açık hipotezi ise, ikiz açık hipotezi sayesinde ortaya atılmıştır. İkiz açık hipotezinin temelinde bütçe açıklarının cari açığın nedeni olduğu yatmaktadır. Diğer bir ifadeyle bütçe açıkları cari açığı ve cari açıkta bütçe açığını karşılıklı olarak etkilemekte yani aralarında aynı yönlü bir ilişki bulunmaktadır. Ayrıca ikiz açık hipotezinde ekonomideki genel dengeden bahsedilirken yatırım-tasarruf dengesi dikkate alınmamakla önemli bir eksiklik ortaya çıkmaktadır. Bu nedenle ikiz açık hipotezine ilave olarak yatırım-tasarruf dengesi değişkeninin de eklenmesiyle üçüz açık hipotezi ortaya çıkmıştır. Özetlemek gerekirse ekonomi de iç dengeyi oluşturan yatırım-tasarruf ile bütçe dengesi ekonomi de diş dengeyi oluşturmuş olan cari dengenin bir arada açık vermesi durumuna "üçüz açık hipotezi" denilmektedir. Diğer bir deyişle ikiz açı hipotezinin genişletilmesiyle yani bütçe ve cari açık değişkenlerine 
yatırım-tasarruf açığının da ilave edilmesiyle üçüz açık ortaya çıkmaktadır (Karanfil \& Kılıç, 2015, s. 2).

\section{2. İKİZ VE ÜÇÜZ AÇIK HİPOTEZI}

Bir ekonomide bütçe giderlerinin bütçe gelirlerinden fazla olduğunu gösteren bütçe açığı ile toplam mal ve hizmet ithalatının toplam mal ve hizmet ihracatından fazla olduğunu gösteren dış ticaret açığı arasındaki ilişki literatürde "İkiz Açık" olarak adlandırılmaktadır. Yine aynı dönemde ekonomide yurtiçindeki toplam yatırımların yurtiçindeki toplam tasarruflardan fazla olması durumunda da yatırım-tasarruf açığı meydana gelmektedir. Bu üç durumun birlikte görülmesi literatürde "Üçüz Açık" olarak ifade edilmektedir (Altun \& İnce, 2014, s. 43). Üçüz Açık Hipotezi bu üç açığın aralarında bir ilişkinin olduğunu ileri sürmektedir.

$\mathrm{Bu}$ durum geleneksel yaklaşım olarak adlandırılan Keynesyen Açı Modelinde şu şekilde gösterilmektedir:

$$
Y=C+I+G+(X-M)
$$

Denklemde; (Y) milli geliri, (C) tüketim harcamalarını, (I) yatırım harcamalarını, (G) kamu harcamalarını, (X) toplam mal ve hizmet ihracatını ve (M) toplam mal ve hizmet ithalatını göstermektedir. Bu denkleme ilave olarak milli gelir (Y), tüketim harcamaları (C), toplam tasarruflar (S) ve vergilerin (T) toplamından da meydana gelmektedir (Günaydın, 2004, s. 145).

$$
Y=C+S+T
$$

Buna göre; her iki denklem birlikte yazıldığında:

$$
(X-M)=(S-I)+(T-G)
$$

sonucuna ulaş1lmaktadır (Akbaş, Lebe \& Zeren, 2014, s. 140).

Denklem (3)'e göre; eşitliğin sol tarafı dış ticaret açığı $(X-M)$, eşitliğin

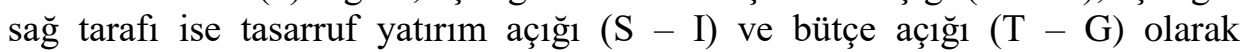
adlandırılmaktadır.

Denklem (3)'ün sağ tarafinda yer alan iki dengenin toplamı ekonominin iç dengesini ve (3) numaralı denklemin sol tarafı da ekonominin dış dengesini belirlemektedir. Yani, iç denge ve diş ekonomik denge birbirlerine eşit olmaktadır ve iç dengede açık ne kadar fazla olursa, dış dengede açık da o kadar fazla olacak demektedir. Bu bağlamda, yurtiçi tasarrufların yurtiçi yatırımlardan daha az olması nedeniyle ortaya çıkan bir tasarruf-yatırım açığı, üçlü açığa neden olmaktadır. Başka bir deyişle, (3) numaralı denklemin sağında yer alan özel sektör tasarruf-yatırım dengesi veya kamu kesimi dengesi ne kadar çok açık verirse ve cari işlemler dengesi de bu açığa eşlik ederse, ekonomide üçüz

\section{4}


açık görülmektedir (Szakolczai, 2006, s. 40).

\section{LITERATÜR İNCELEMESI}

Literatürde "İkiz Açık Hipotezi" ne ilişkin yapılmış olan çok sayıda çalışma olmasına rağmen tasarruf-yatırım açığını da dikkate alarak yapılan "Üçüz Açık Hipotezi” ile ilgili az sayıda çalışma yer almaktadır. Yapılan çalışmalarda incelenen ülkelerin farklı olması, çalışmalarda kullanılan dönemlere ilişkin veri setleri ve uygulanan yöntemlerin farklıl1k göstermesinden dolayı gerek "İkiz Açık" gerekse "Üçüz Açık" hipotezlerine ilişkin bulunan sonuçlarda ortak bir fikir birliğine ulaşılamamıştır.

İkiz açıklarla ilgili olarak yapılan uluslararası çalışmalarda; Salvatore (2006), G7 ülkeleri için bütçe açıkları ile cari açığın aralarında nedenselliğin olup olmadığını incelediği çalışmasında, değişkenler arasında tek yönlü bir nedensellik olduğu sonucuna ulaşmıştır. Marinheiro (2008), 1974-1989 dönemleri arasında Mısır'da, bütçe açığı ile cari açık arasında Granger nedenselliğin olup olmadığını incelediği çalışmasında, cari açıktan bütçe açığına doğru tek yönlü bir nedenselliğin olduğu sonucuna ulaşmıştır. Hakro (2009), 1948-2005 dönemleri arasında Pakistan'da bütçe açığı ile cari açık arasında Granger nedenselliğin olup olmadığını incelediği çalışmasında, değişkenler arasında çift yönlü bir nedensellik olduğu sonucuna ulaşmıştır. Baharumshah \& Lau (2009), 1980-2006 dönemleri arasında çeyrek dönemlik veriler kullanarak 7 Doğu Asya ülkesini kapsadığı çalışmalarında, 5 ülkede bütçe açığından cari açığa tek yönlü bir nedenselliğin olduğu sonucuna ulaşmıştır. Omoniyi, Olasunkanmi \& Babatunde (2012), 1970-2008 dönemleri arasında Nijerya'da bütçe açığı ile cari açığın aralarındaki ilişkiyi Johansen eşbütünleşme ve Granger nedensellik yöntemleriyle incelediği çalışmalarında, iki değişkenin uzun dönemde birlikte hareket ettiği ve değişkenler arasında karşılıklı bir ilişki olduğu sonucuna ulaşmışlardır.

Feldstein (1992), 1980-1990 dönemleri arasında ABD'de bütçe açığı ile cari açığın aralarında bir ilişki olup olmadığını regresyon analizi yaparak incelediği çalışmasında, ikiz açık hipotezinin geçerli olmadığı sonucuna ulaşmıştır. Rahman \& Mishra (1992), 1946-1988 dönemleri arasında ABD'de bütçe açığı ile cari açığın aralarındaki ilişsiyi eşbütünleşme analiziyle inceledikleri çalışmalarında, değişkenler arasında uzun dönemli bir ilişkinin olmadığı sonucuna varmıştır. Kaufman, Scharler \& Winckler (2002), 19761997 dönemleri arasında çeyrek dönemlik veriler kullanarak Avusturya'da cari açık ile bütçe açığı arasındaki ilişkiyi Johansen eşbütünleşme ve Vektör Hata Düzeltme modelleri yardımıyla araştırdıkları çalışmalarında, değişkenler arasında uzun dönemde bir ilişki olmadığı sonucuna ulaşmışlardır. Afonso \& Rault (2009), 1970-2007 dönemleri arasında AB ve OECD ülkelerini 
kapsayarak Panel eşbütünleşme analiziyle bütçe açığı ve cari açık arasındaki ilişkiyi inceledikleri çalışmalarında, değişkenler arasında uzun dönemli bir ilişkinin olmadığı sonucuna ulaşmışlardır. Daly \& Siddiki (2009), 1960-2000 dönemleri arasında 23 OECD ülkesini kapsayarak yapısal kırılmalı eşbütünleşme analizi yaptıkları çalışmalarında, Almanya, İngiltere, ABD, Kanada ve İsveç’te bütçe açı̆̆ ile cari açığın aralarında uzun dönemde bir ilişki olmadığı sonucuna ulaşmışlardır.

İkiz açıklarla ilgili olarak Türkiye'de yapılan çalışmalar incelendiğinde de farklı sonuçlarla karşıılaşılmaktadır. Erdinç (2008), 1950-2005 dönemleri arasında cari açıkla bütçe açığı arasındaki ilişkiyi Johansen eşbütünleşme ve Granger nedensellik analizleriyle incelediği çalışmasında, değişkenler arasında uzun dönemli bir ilişki olduğu ve bütçe açığından cari açığa doğru tek yönlü bir nedenselliğin olduğu sonucuna ulaşmıştır. Çelik, Deniz \& Seden (2008), 19962006 dönemleri arasında çeyrek dönemlik veriler kullanarak Türkiye ve benzer ekonomilere sahip 5 ülkenin yer aldığ1 pedroni panel eşbütünleşme analizi ile bütçe ve cari açık arasındaki ilişkiyi araştırdıkları çalışmalarında, 6 ülke içinde değişkenlerin aralarında uzun dönemde ilişki olduğu sonucuna ulaşmışlardır. Bolat, Belke \& Aras (2011), 1998-2010 dönemleri arasında çeyrek dönemlik veriler kullanarak cari açıkla bütçe açığı arasındaki ilişkiyi ARDL sınır testiyle inceledikleri çalışmalarında, değişkenlerin aralarında uzun dönemde ilişki olmadığına ancak kısa dönemde değişkenlerin arasında pozitif güçlü bir ilişki olduğu sonucuna ulaşmışlardır.

Bayrak \& Esen (2012), 1975-2010 dönemleri arasında bütçe açığı ile cari işlemler dengesinin aralarındaki ilişkiyi Johansen eşbütünleşme ve hata düzeltme modeliyle inceledikleri çalıșmalarında, incelenen dönemde bütçe açıkları ile cari işlemler açıkları arasında hem kısa hem de uzun dönemli bir ilişki olduğu sonucuna ulaşmışlardır. Mangır (2012), 1980-2011 dönemleri arasında bütçe açığı ile cari açığın arasındaki ilişkiyi Johansen eşbütünleşme ve Graner nedensellik testleriyle incelediği çalışmasında, değiş̧enler arasında uzun dönemli bir ilişki olduğu ve bütçe açığından cari açığa doğru tek yönlü bir nedensellik olduğu sonucuna ulaşmıştır. Kılavuz \& Dumrul (2012), 2006-2010 dönemleri arasında aylık veriler kullanarak cari açık ile bütçe açığının aralarındaki ilişkiyi ARDL sınır ve Granger nedensellik testlerini kullanarak inceledikleri çalışmalarında, değişkenler arasında çift yönlü bir nedensellik olduğunu ama değişkenler arasında uzun dönemli bir ilişki olmadığı sonucuna ulaşmışlardır.

İyidoğan \& Erkam (2013), 1987-2005 dönemleri arasında çeyrek dönemlik veriler kullanarak bütçe açı̆̆ı ve cari açığın ilişkisini Granger nedensellik testiyle inceledikleri çalışmalarında, incelenen dönem açısından iki değişken arasında nedensellik ilişkisi olmadığı sonucuna ulaşmışlardır. Üzümcü 
\& Kanca (2013), 1980-2012 dönemleri arasında yıllık veriler kullanarak bütçe açığı ile cari açık arasındaki ilişkiyi en küçük kareler, Johansen eşbütünleșme ve Granger nedensellik testleriyle inceledikleri çalışmalarında, değişkenler arasında uzun dönemli bir ilişki olduğunu ancak iki değişken arasında nedensellik ilişkisi olmadığı sonucuna ulaşmışlardır. Azapoğlu \& Direkçi (2015), 1998-2011 dönemleri arasında çeyrek dönemlik veriler kullanarak cari açık ile bütçe açığı arasındaki ilişkiyi Johansen eşbütünleşme analizi, hata düzeltme modeli ve Granger nedensellik testiyle inceledikleri çalışmalarında, değiş̧kenler arasında uzun dönemli bir ilişki olduğu ve bütçe açıklarından cari açığa doğru tek yönlü bir nedenselliğin olduğu sonucuna ulaşmışlardır. Dineri \& Taş (2016), 1980-2015 dönemleri arasında bütçe açığı ile cari açık arasındaki ilişkiyi Johansen eşbütünleşme ve Granger nedensellik testlerini kullanarak inceledikleri çalışmalarında, cari açıktan bütçe açığına doğru tek yönlü bir nedenselliğin olduğu sonucuna ulaşmışlardır.

"İkiz Açık Hipotezi” ne ilave olarak tasarruf-yatırım açığı değişkeninin de analizlere eklenmesiyle ortaya çıkan "Üçüz Açık Hipotezi" ne ilişkin ulusal ve uluslararası düzeyde yapılmış çalışmalar az sayıdadır.

Chowdhury \& Saleh (2007), 1970-2005 dönemleri arasında Sri Lanka'da üçüz açık hipotezinin geçerliliğini (ARDL) sınır testiyle araştırdıkları çalışmalarında, değişkenlerin aralarında uzun dönemli bir ilişki olduğu sonucuna ulaşmıştır. Şengönül (2008), 1994-2006 dönemleri arasında çeyrek dönemlik veriler kullanarak Türkiye'de üçüz açık hipotezinin geçerliliğini ARDL sınır testiyle araştırdığı çalışmasında, değişkenler arasında uzun dönemli bir ilişki olduğu sonucuna ulaşmıştır. Türkay (2013), 1980-2012 dönemleri arasında Türkiye'de cari açık, bütçe açığı ve yatırım-tasarruf açığı değişkenleri arasındaki ilişkiyi Engle-Granger eşbütünleşme ve Dinamik En Küçük Kareler yöntemini kullanarak incelediği çalışmasında, değişkenler arasında uzun dönemli bir ilişki olduğu sonucuna ulaşmıştır.

Tülümce (2013), 1984-2010 dönemleri arasında Türkiye'de üçüz açık sorununun olup olmadığını Vektör Otoregresif (VAR) modeliyle incelediği çalışmasında, cari açıkla tasarruf-yatırım arasında ilişki olduğu ancak cari açıkla bütçe açığının aralarında bir ilişkinin olmadığı dolayısıyla üçüz açık hipotezinin Türkiye'de geçerli olmadığı sonucuna ulaşmıştır. Altun \& İnce (2014), 1975 2010 dönemleri arasında Türkiye'de Üçüz Açık Hipotezi'nin geçerli olup olmadığını ARDL sınır testi ve Toda Yamamoto nedensellik testini kullanarak inceledikleri çalışmalarında, değiş̧kenler arasında eşbütünleşmeye rastlamamışlardır. Ayrıca yapmış oldukları nedensellik testi sonuçlarında ise cari açıktan tasarruf-yatırım açığına ve bütçe açığına, tasarruf-yatırım açığından da bütçe açı̆̆ına doğru tek yönlü bir nedensellik olduğu sonucuna ulaşmışlardır. Tang (2014), 1960- 2013 dönemleri arasında çeyrek dönemlik veriler kullanarak 
ABD'de üçüz açık hipotezinin geçerli olup olmadığını ARDL sınır testini kullanarak incelediği çalışmasında, değişkenlerin uzun dönemde birlikte hareket ettiği sonucuna ulaşmıştır.

Berke vd., (2015), 2003-2012 dönemleri arasında üçer aylık verileri kullanarak Üçüz Açık ile ekonomik büyüme arasındaki ilişkiyi Vektör Otoregresif (VAR) modeliyle incelediği çalışmalarında, üçüz açığı oluşturan değişkenlerin ekonomik büyümeyi negatif yönde etkilediği sonucuna ulaşmışlardır. Karanfil \& Kılıç (2015), 1980-2013 dönemleri arasında Türkiye'de üçüz açık hipotezinin geçerli olup olmadığını Johansen eşbütünleşme ve Granger nedensellik analizlerini kullanarak inceledikleri çalışmalarında, değişkenlerin aralarında uzun dönemde ilişki olduğu sonucuna varmışlardır. Ayrıca cari açıktan tasarruf ve bütçe açı̆̆ına doğru tek yönlü, tasarruf açığından bütçe açığına doğru çift yönlü bir nedenselliğin olduğu sonucuna ulaşmışlardır. Güder \& Kılıç (2016), 1980-2012 dönemleri arasında üçüz açığı oluşturan değişkenler ile ekonomik büyüme arasındaki ilişkiyi Vektör Otoregresif (VAR) modeliyle incelediği çalışmalarında, üçüz açı değişkenlerinden bütçe açığının kısa dönemde büyümeyi olumlu uzun dönemde olumsuz etkilediğini tespit etmişlerdir. Ayrıca tasarruf yatırım açıklarının ekonomik büyümenin olumsuz olarak etkilenmesine yol açtığı ve cari açığın ekonomik büyümede olumlu etkiler yarattığı sonucuna ulaşmışlardır.

Şen \& Kaya (2016), 1994-2012 dönemleri arasında 6 post-komünist ülkede ikiz veya üçüz açık hipotezinin geçerli olup olmadığını Bootstrap panel Granger nedensellik testiyle inceledikleri çalışmalarında, incelenen ülkelerin hiçbirinde ne ikiz ne de üçüz açık hipotezinin geçerli olmadığı sonucuna ulaşmışlardır. İpek \& Kızılgöl (2016), 2004-2014 dönemleri arasında çeyrek dönemlik veriler kullanarak Türkiye'de üçüz açık hipotezinin geçerli olup olmadığını ARDL sınır testi ve Toda Yamamoto nedensellik testini kullanarak inceledikleri çalışmalarında, değişkenler arasında uzun dönemli bir eşbütünleşmenin olduğunu tespit etmişlerdir. Ayrıca yapmış oldukları nedensellik testi sonuçlarında ise bütçe açığı ve cari açık, bütçe açığı ve tasarruf-yatırım açığ 1 ve cari açıkla yatırım-tasarruf açığ 1 arasında çift yönlü bir nedenselliğin olduğu sonucuna ulaşmışlardır. Shastri, Giri \& Mohapatra (2017), 1985-2015 dönemleri arasında 5 Güney Asya ülkesinde üçüz açık hipotezinin geçerliliğini Pedroni ve Westerlund panel eşbütünleşme testleriyle inceledikleri çalışmalarında, her iki eşbütünleşme testi sonuçlarına göre değişkenlerin aralarında uzun dönemli bir ilişki olduğunu tespit etmişlerdir.

\section{EKONOMETRIKK MODEL VE METODOLOJİ}

\subsection{Model ve Veri Seti}

Bu çalışmada, Türkiye'de ekonomik büyüme, cari açı, bütçe açığı ve 508 
tasarruf-yatırım açı̆̆ı arasındaki ilişki Vektör Otoregresif (VAR) analizi kullanılarak açıklanmaya çalıșılacaktır. VAR analizinin kullanılma nedeni, değişkenlerin birbirleri üzerindeki etkilerini gösterme olanağı sağlamasıdır. Çalışmada yer alan değişkenlere iliş̧in veriler 1975-2016 dönemine ait yıllık zaman serileridir. Değişkenlere ait veriler Kalkınma Bakanlığı, Maliye Bakanlığı ve Dünya Bankası'ndan elde edilmiştir. Çalışmada kullanılmakta olan veriler oran olduğundan dolayı değişkenlerin logaritması alınmamıştır.

Tablo 1: Değişkenlerin Tanımlanması

\begin{tabular}{lll}
\hline Değişkenler & \multicolumn{1}{c}{ Açıklama } & \multicolumn{1}{c}{ Kaynak } \\
\hline BAC & Bütçe Açığının Reel GSYİH'ya Oranı (\%) & $\begin{array}{l}\text { Kalkınma Bakanlığı, } \\
\text { Maliye Bakanlığı }\end{array}$ \\
\hline TYAC & $\begin{array}{l}\text { Özel Tasarruf-Özel Yatırım Açı̆̆ının Reel } \\
\text { GSYİH'ya Oranı (\%) }\end{array}$ & Kalkınma Bakanlığı \\
\hline CAC & Cari Açı̆̆ın Reel GSYİH'ya Oranı (\%) & Dünya Bankası \\
\hline BUYUME & Reel GSYİH'daki (\%) Değişim & Dünya Bankası \\
\hline
\end{tabular}

Çalışmada yer alan değişkenlere ait tanımlayıcı istatistikler ve korelasyon matrisi aşağıda Tablo 2'de verilmiştir.

Tablo 2: Tanımlayıcı İstatistikler ve Korelasyon Matrisi (Zaman Serisi: 1975-2016)

\begin{tabular}{ccccc}
\hline İstatistikler/Değişkenler & BUYUME & BAC & CAC & TYAC \\
\hline Ortalama & 4.516667 & -3.309524 & -2.611905 & 1.642857 \\
Medyan & 5.100000 & -2.200000 & -2.400000 & 2.200000 \\
Maksimum & 11.10000 & -0.100000 & 2.000000 & 13.80000 \\
Minimum & -6.000000 & -11.90000 & -8.900000 & -7.300000 \\
Standart Sapma & 4.327728 & 2.902296 & 2.459645 & 5.432654 \\
Çarpıklık & -0.803052 & -1.481671 & -0.122692 & 0.158381 \\
Basıklık & 2.912265 & 4.507357 & 2.737617 & 2.029810 \\
Jargue-Bera & 4.527717 & 19.34366 & 0.225853 & 1.822811 \\
Olasılık & 0.103949 & 0.000063 & 0.893216 & 0.401959 \\
Gözlem Sayısı & 42 & 42 & 42 & 42 \\
BUYUME & 1 & 0.287484 & -0.492612 & -0.301623 \\
BAC & 0.287484 & 1 & -0.412886 & -0.668513 \\
CAC & -0.492612 & -0.412886 & 1 & 0.779378 \\
TYAC & -0.301623 & -0.668513 & 0.779378 & 1 \\
\hline
\end{tabular}

\subsection{Birim Kök Testleri}

Zaman serilerini içeren çalışmalarda serilerin birim kök içerip içermediklerini yani durağan olup olmadıklarını belirleyebilmek ve hangi düzeyde durağan olduklarını göstermek amacıyla geliştirilmiş pek çok durağanlık testi vardır. Çalışmada yer alan değișkenlere ilişkin durağanlık analizlerinde uygulamada çok sık kullanılmakta olan ADF ve PP testlerine yer 
verilmiștir.

\subsubsection{Genişletilmiş Dickey-Fuller Testi (ADF)}

ADF testi, bağımlı değişkenin gecikmeli değerlerinin, bağımsız değişken olarak modele ilave edilmesiyle elde edilir (Enders, 1995, s. 225).

Trendsiz ve Sabit Terimsiz: $\Delta Y_{t}=\gamma Y_{t-1}+\sum_{i=2}^{m} \beta_{i} \Delta Y_{t-i+1}+\varepsilon_{t}$

Sabit Terimli: $\Delta Y_{t}=\alpha_{0}+\gamma Y_{t-1}+\sum_{i=2}^{m} \beta_{i} \Delta Y_{t-i+1}+\varepsilon_{t}$

Trendli ve Sabit Terimli: $\Delta Y_{t}=\alpha_{0}+\beta_{t}+\gamma Y_{t-1}+\sum_{i=2}^{m} \beta_{i} \Delta Y_{t-i+1}+\varepsilon_{t}$

Test sonucuna göre $\tau$ değeri Dickey-Fuller tarafından hesaplanmış olan MacKinnon (1996) tarafindan tekrar düzenlenmiş tablo değerleriyle karşılaştırarak $\gamma=0$ hipotezi test edilmektedir (Enders, 1995, s. 221). Sifır hipotezi $\left(H_{0}: \gamma=0\right)$ serinin durağan dış1 olduğunu ve birim kök içerdiğini, alternatif hipotez $\left(H_{l}: \quad \gamma \neq 0\right)$ ise serinin durağan olduğu ve birim kök içermediğini göstermektedir.

\subsubsection{Phillips-Perron Testi}

Phillips ve Perron (1988) geliştirdikleri bir yöntemle Dickey-Fuller yöntemi kapsamında bu varsayımı yumuşatmışlardır (Kutlar, 2007, s. 335).

Aşağıdaki denklem modellerini ele alırsak,

$$
\begin{aligned}
& Y_{t}=m_{0}+m_{1} y_{t-1}+e_{t} \\
& y_{t}=m *_{0}+m *_{1} y_{t-1}+m *_{2}\left(t-\frac{T}{2}\right)+e_{t}
\end{aligned}
$$

Denklemlerde $T$ gözlem sayısını göstermektedir. $E\left(e_{t}\right)=0$ olduğundan hata terimlerinin otokorelasyonsuz olması veya homojen olmamaları için bir zorunluluk gerektirmemektedir. Phillips ve Peron (PP) testi, DF testinin tersine hata terimleri arasında zayıf bağımlılığa ve heterojenliğe izin vermektedir. PP testi,

$$
y_{t}=y_{t-1}+e_{t}
$$

sürecinde üretilmiş olan verilerin, $m$ ve $m^{*}$ ile $m_{1}$ katsayılarına karşı sıfır hipotezi sınamasına başvurulur.

\subsection{Var Analizi}

VAR, tek değişkenden oluşan AR modellerini genelleştirerek çok değişkenli zaman serilerinin aralarındaki ilişkileri ve karş1lıklı etkileşimlerinin görülmesini sağlayan ekonometrik bir modeldir. VAR modeli içinde yer alan tüm değiş̧kenlerin kendi gecikmelerinin ve diğer değişkenlerin gecikmelerinin yer aldığı, buna göre her bir değişkenin diğer değişkenlerle etkileşiminin 
simetrik olarak sağlandığı bir denklem sistemidir. VAR modelleri makroekonomik değișkenlerin aralarındaki ilişkilerinin incelenmesinde ve tesadüfi şokların değişkenler üzerindeki dinamik etkilerinin analizlerinde kullanılmaktadır (Özgen \& Güloğlu, 2004, s. 97).

$$
\begin{aligned}
& \triangle B U Y U M E_{t}=\alpha_{1}+\beta_{1} \Delta B A C_{t-1}+\delta_{1} \Delta C A C_{t-1}+\mu_{1} \Delta T Y A C_{t-1}+ \\
& \theta_{1} \Delta B U Y U M E_{t-1}+\varepsilon_{1 t} \\
& \Delta B A C_{t}=\alpha_{1}+\beta_{2} \Delta C A C_{t-1}+\delta_{2} \Delta T Y A C_{t-1}+\mu_{2} \Delta B U Y U M E_{t-1}+ \\
& \theta_{2} \Delta B A C_{t-1}+\varepsilon_{2 t} \\
& \Delta C A C_{t}=\alpha_{1}+\beta_{3} \Delta T Y A C_{t-1}+\delta_{3} \Delta B U Y U M E_{t-1}+\mu_{3} \Delta B A C_{t-1}+ \\
& \theta_{3} \Delta C A C_{t-1}+\varepsilon_{3 t} \\
& \Delta T Y A C_{t}=\alpha_{1}+\beta_{4} \Delta B U Y U M E_{t-1}+\delta_{4} \Delta B A C_{t-1}+\mu_{4} \Delta C A C_{t-1}+ \\
& \theta_{4} \Delta T Y A C_{t-1}+\varepsilon_{4 t}
\end{aligned}
$$

Burada t zamanı; $\beta, \delta, \mu, \theta$ katsayıları; $\Delta$ fark operatörünü; $\alpha$ sabit terimi;

\begin{tabular}{|c|c|c|c|c|c|}
\hline \multirow[b]{2}{*}{ Değişkenler } & & \multicolumn{2}{|c|}{ ADF TESTI } & \multicolumn{2}{|c|}{ PP TESTİ } \\
\hline & & t-istatistiği & p-değeri & t-istatistiği & p-değeri \\
\hline & Sabit Terimli & -6.168862 & $0.0000 *$ & -6.165573 & $0.0000 *$ \\
\hline \multirow[t]{2}{*}{ BUYUME } & Trendli-Sabitli & -6.171294 & $0.0000 *$ & -6.252788 & $0.0000 *$ \\
\hline & Sabit Terimli & -2.130863 & 0.2341 & -2.267792 & 0.1869 \\
\hline \multirow[t]{2}{*}{ BAC } & Trendli-Sabitli & -1.962344 & 0.6039 & -2.108322 & 0.5260 \\
\hline & Sabit Terimli & -3.371217 & $0.0179 * *$ & -3.457245 & $0.0144 * *$ \\
\hline \multirow[t]{2}{*}{ CAC } & Trendli-Sabitli & -3.742585 & $0.0305 * *$ & -3.776520 & $0.0281 * *$ \\
\hline & Sabit Terimli & -1.888700 & 0.3342 & -1.955828 & 0.3045 \\
\hline TYAC & Trendli-Sabitli & -2.056860 & 0.5536 & -2.063067 & 0.5503 \\
\hline
\end{tabular}
$\varepsilon$ hata terimini göstermektedir.

\section{AMPİRIK BULGULAR}

Ekonomik büyüme, bütçe açığı, cari açık ve tasarruf-yatırım açığı değişkenleri arasındaki ilişkinin analiz edilebilmesi amacıyla ilk olarak değişkenlerin durağanlık düzeyleri ADF ve PP birim kök testleri ile incelenmiş ve elde edilen sonuçlar Tablo 3 ve Tablo 4'de verilmiştir.

Tablo 3: ADF ve PP Birim Kök Test Sonuçları (Düzey Değerleri)

Birim kök testleri düzey değerleri sonuçlarına bakıldığında, BUYUME ve 
CAC değişkenlerinin düzeyde durağan oldukları, BAC ve TYAC değiş̧kenlerinin ise düzeyde durağan olmadıkları görülmektedir. Bu nedenle BAC ve TYAC değişkenlerin 1. farkları alınıp durağanlık durumları tekrar incelenecektir.

Tablo 4: ADF ve PP Birim Kök Test Sonuçları (Birinci Farklar)

\begin{tabular}{|c|c|c|c|c|c|}
\hline \multirow[b]{2}{*}{ Değişkenler } & & \multicolumn{2}{|c|}{ ADF TESTI } & \multicolumn{2}{|c|}{ PP TESTI } \\
\hline & & $\mathrm{t}$-istatistiği & p-değeri & $\mathrm{t}$-istatistiği & p-değeri \\
\hline & Sabit Terimli & -6.206067 & $0.0000 *$ & -6.206067 & $0.0000 *$ \\
\hline \multirow[t]{2}{*}{$\mathrm{BAC}$} & Trendli-Sabitli & -6.219226 & $0.0000^{*}$ & -6.219226 & $0.0000 *$ \\
\hline & Sabit Terimli & -6.797788 & $0.0000^{*}$ & -6.790052 & $0.0000^{*}$ \\
\hline TYAC & Trendli-Sabitli & -6.720675 & $0.0000 *$ & -6.715623 & $0.0000 *$ \\
\hline
\end{tabular}

Birim kök testleri birinci farkları sonuçlarına bakıldığında, düzeyde durağan olmayan BAC ve TYAC değişkenlerinin farkları alındıktan sonra durağan hale geldikleri görülmektedir. Birim kök analizi sonuçları incelendiğinde, BUYUME ve CAC değişkenlerinin $\mathrm{I}(0)$, BAC ve TYAC değişkenlerinin I(1) olduğu görülmektedir.

Değişkenlerin durağanlıkları elde edildikten sonra değişkenler arasındaki ilişkilerin incelenebilmesi için VAR modeline geçilebilir. Ancak VAR modelinde gecikme seviyesi önemlidir. Bu nedenle optimum gecikme için bilgi kriterlerine başvurulması gerekmektedir.

Tablo 5: VAR Modeliyle Optimal Gecikme Sayılarının Belirlenmesi

\begin{tabular}{|c|c|c|c|c|c|}
\hline Gecikme & LR & FPE & AIC & SC & HQ \\
\hline 0 & NA & 1869.380 & 18.88482 & 19.05897 & 18.94621 \\
\hline 1 & $50.07910^{*}$ & $934.3546 *$ & $18.18471^{*}$ & $19.05548 *$ & $18.49170 *$ \\
\hline 2 & 15.74071 & 1307.275 & 18.48741 & 20.05479 & 19.03998 \\
\hline 3 & 21.26527 & 1393.783 & 18.46622 & 20.73021 & 19.26438 \\
\hline 4 & 13.59831 & 1992.194 & 18.65117 & 21.61177 & 19.69492 \\
\hline
\end{tabular}

Tablo sonuçları incelendiğinde, tüm kriterler için minimum gecikme sayısının 1 olduğu görülmektedir. $\mathrm{Bu}$ sonuçlar VAR modelinde uygun gecikmenin 1 olacağına karar verilmiştir.

VAR modelinin sonuçlarını etkileyecek diğer önemli durum, değisskenlerin VAR analizinde hangi sırada yer alacağıdır. $\mathrm{Bu}$ sıralamayı belirlerken Kim ve Roubini (2008)'nin çalışmalarında yapmış oldukları

\section{2}


sıralamaya göre VAR analizi yapılacaktır.

Tablo 6: VAR Modeli Sıralaması

\begin{tabular}{llllll}
$\begin{array}{l}\text { Ekonomik Büyüme } \\
\text { Açığı }\end{array}$ & $\rightarrow$ Bütçe Açı̆̆ı & $\rightarrow$ & Cari Açık & $\rightarrow$ & Tasarruf-Yatırım \\
BUYUME & $\rightarrow$ & BAC & $\rightarrow$ & CAC $\rightarrow$ & TYAC \\
\hline
\end{tabular}

Değişkenlerin durağan olup olmadıklarının sınanması, VAR modeli için en uygun gecikme uzunluğunun hesaplanması ve değişkenlerin sıralamaları belirlendikten sonra VAR analizine geçilebilir. Kurulan modelde yer alan değiş̧kenlerin şoklar karşısında verdikleri tepkileri belirlemek için etki-tepki analizi ve varyans ayrıştırması yapılacaktır. Ayrıca modelde otokorelasyon ve değişen varyans sorunu olup olmadığı araştırılacaktır.

Response to Cholesky One S.D. Innovations \pm 2 S.E.

Response of BUYUME to BUYUME

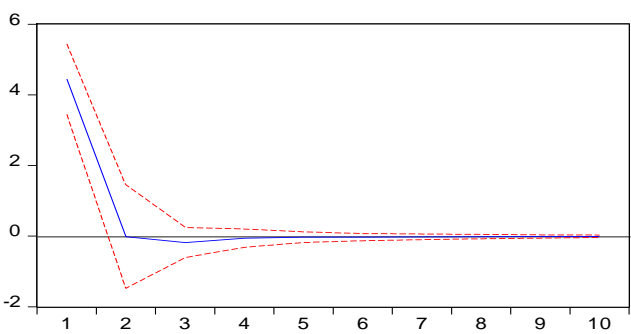

Response of CAC to BUYUME

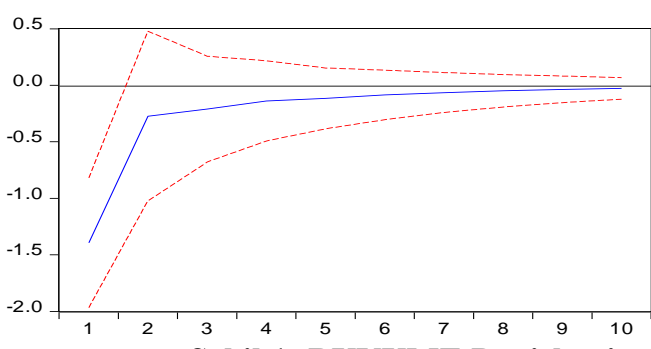

Şekil 1: BUYUME Değişkenine Verilen Şoka Değişkenlerin Tepkisi
Response of $\mathrm{D}(\mathrm{BAC})$ to $\mathrm{BUYUME}$

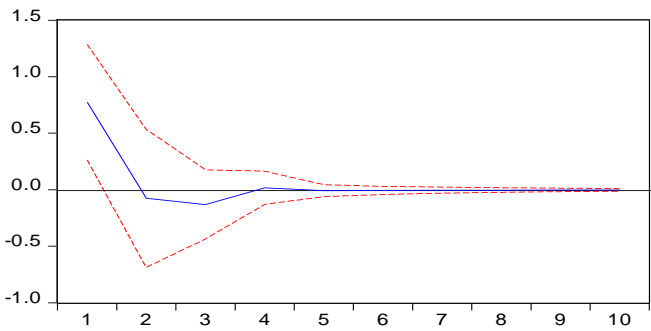

Response of D(TYAC) to BUYUME

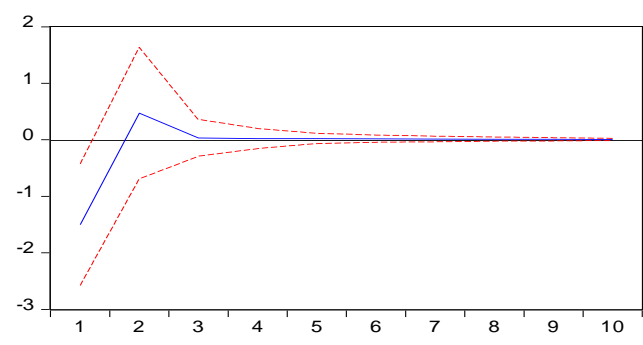

Grafikler incelendiğinde, ekonomik büyüme (BUYUME) değişkenine verilen pozitif bir şok karşısında değişkenin kendisi azalarak da olsa iki dönem boyunca pozitif yönde tepki vermiş daha sonra üçüncü dönemde az da olsa tepki negatife inmiş olsa da dördüncü dönemden itibaren şokun etkisi anlamlılığını yitirmiştir. Yine ekonomik büyüme (BUYUME) değişkenine verilen pozitif şoka bütçe açı̆̆g (BAC) değişkeni ikinci döneme kadar pozitif, ikinci dönemden dördüncü döneme kadar negatif tepki verdikten sonra şokun etkisi anlamlılığını yitirmiştir. Burada ekonomik büyümenin kısa dönemde bütçe açıklarını artırdığı 
ancak uzun dönemde ise azalttığı sonucu çıkarılabilir. Cari açık (CAC) değişkeni ise verilen şoka ilk iki dönem daha fazla olmakla birlikte onuncu dönemin sonuna kadar negatif tepki vermiştir. Buradan ekonomik büyümenin kısa dönemde daha fazla olmakla birlikte hem kısa hem de uzun dönemde cari açığı azalttığı sonucu çıkarılabilir. Tasarruf-yatırım açığı (TYAC) değişkeni, verilen şoka ikinci döneme kadar negatif, daha sonra üçüncü dönemin sonuna kadar pozitif tepki vermiş ve şokun etkisi anlamlılığını yitirmiştir. Buradan da ekonomik büyümenin kısa dönemde önce tasarruf-yatırım açı̆̆ını azalttığı ancak daha sonra da artırdığı sonucu çıkarılabilir. Bu açıklamalara göre ekonomik büyümede oluşabilecek pozitif bir şokun kısa dönemde bütçe açıklarını artırırken, tasarruf-yatırım açıklarını azalttığı ve daha sonra da bütçe açıkları azalırken de tasarruf-yatırım açıklarının artırdığı dolayısıyla ekonomik büyümeye, kısa dönemde bütçe açıkları ile tasarruf-yatırım açıkları birbirlerinin tersi şeklinde tepki verdikleri sonucu çıkarılabilir.

Response to Cholesky One S.D. Innovations \pm 2 S.E.

Response of BUYUME to D(BAC)

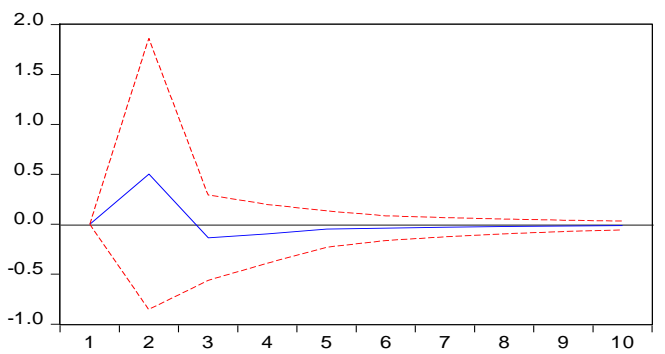

Response of $\mathrm{CAC}$ to $\mathrm{D}(\mathrm{BAC})$

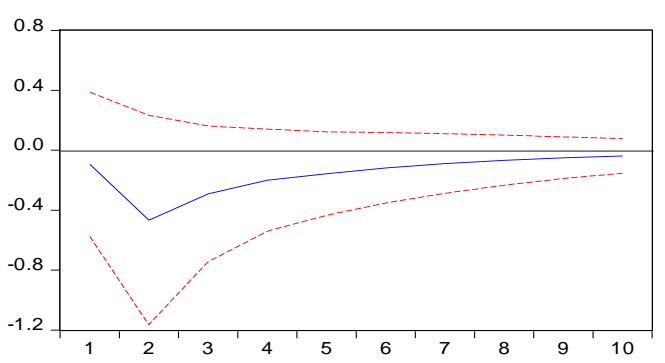

Response of $\mathrm{D}(\mathrm{BAC})$ to $\mathrm{D}(\mathrm{BAC})$

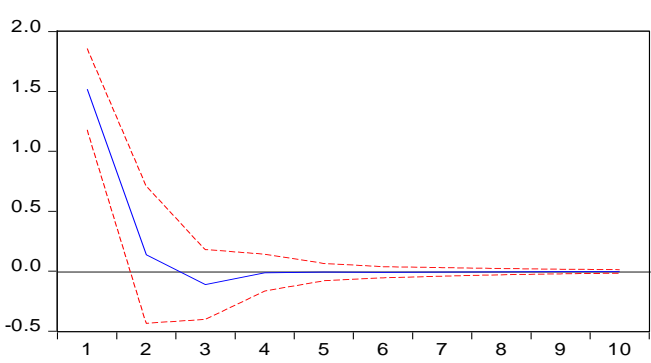

Response of $\mathrm{D}$ (TYAC) to $\mathrm{D}(\mathrm{BAC})$

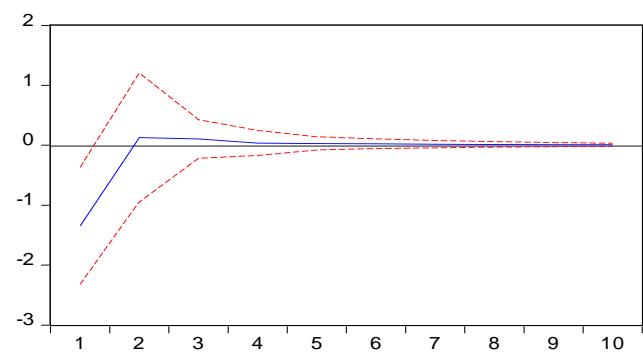

Şekil 2: BAC Değişkenine Verilen Şoka Değişkenlerin Tepkisi

Bütçe açı̆̆ı (BAC) değişkenine verilen pozitif bir şok karşısında, ekonomik büyüme (BUYUME) değişkeni üçüncü döneme kadar pozitif, üçüncü dönemden yedinci dönemin sonuna kadar az da olsa negatif yönde tepki vermiş ve daha sonra şokun etkisi anlamlılığını yitirmiştir. Buradan bütçe açıklarının kısa dönemde ekonomik büyümede olumlu etki yarattığı ancak uzun dönemde

\section{4}


ekonomik büyüme üzerinde olumsuz etki yarattığı sonucu çıkarılabilir. Bütçe açığ 1 değişkenine verilen pozitif bir şoka değişkenin kendisi azalarak da olsa ikinci dönemin sonuna kadar pozitif, daha sonra üçüncü dönemden dördüncü döneme kadar negatif tepki vermiş ve sonra şokun etkisi anlamlılığını yitirmiş̧ir. Cari açık (CAC) değişkeni ise verilen şoka ikinci ve üçüncü dönem arasında daha fazla olmakla birlikte onuncu dönemin sonuna kadar negatif yönde tepki vermiştir. Buradan bütçe açığı ile cari açık arasında incelenen dönemde ters yönlü bir ilişki olduğu yani bütçe açığı artarken cari açığın azaldığ1 ve bütçe açığı azalırken de cari açığın arttığı sonucu çıkarılabilir. Tasarruf-yatırım açığı (TYAC) değişkeni, verilen şoka ikinci döneme kadar negatif, daha sonra az da olsa dördüncü döneme kadar pozitif bir tepki vermiş ve şokun etkisi anlamlılığını yitirmiştir. Buradan da bütçe açığı ile tasarrufyatırım açığının aralarında kısa dönemde ters yönlü bir ilişki olduğu ancak bu durumun daha sonra aynı yönlü olarak değiştiği sonucu çıkarılabilir.

Response to Cholesky One S.D. Innovations \pm 2 S.E.

Response of BUYUME to CAC

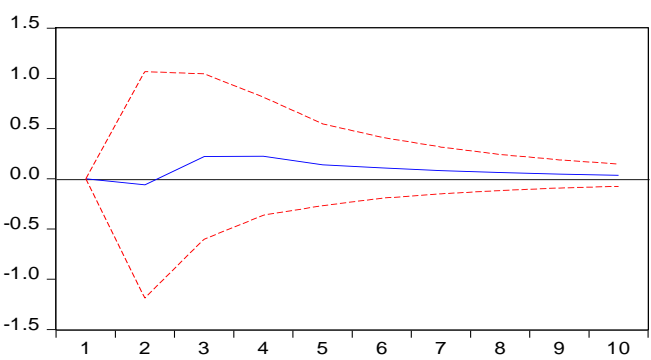

Response of CAC to CAC

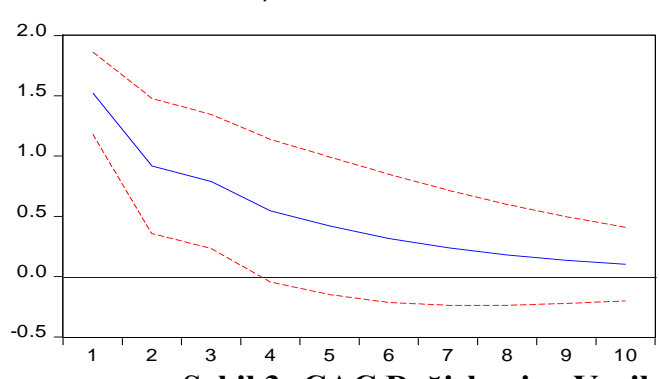

Şekil 3: CAC Değişkenine Verilen Şoka Değişkenlerin Tepkisi
Response of $D(B A C)$ to $C A C$

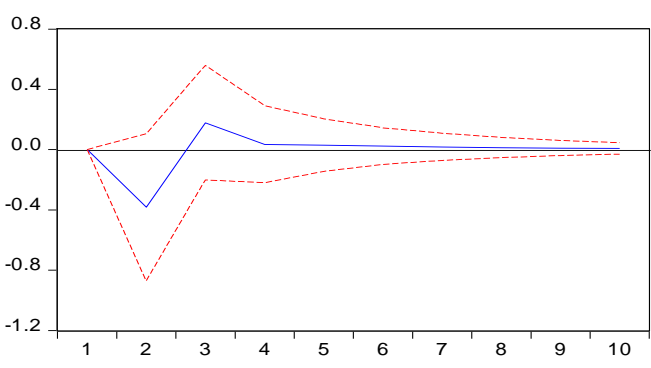

Response of D(TYAC) to CAC

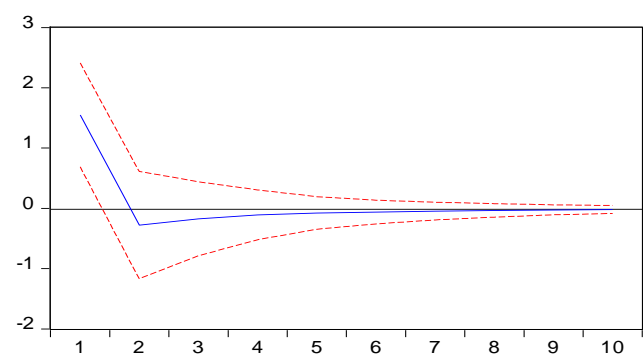

Cari açık (CAC) değişkenine verilen pozitif bir şok karşısında, ekonomik büyüme (BUYUME) değişkeni ikinci döneme kadar az da olsa negatif, üçüncü dönemden onuncu döneme kadar pozitif yönde tepki vermiştir. Buradan kısa dönemde, cari açıktaki pozitif bir etkinin ekonomik büyümeyi olumsuz etkilemesine karşın uzun dönemde cari açığın ekonomik büyümeyi olumlu 
yönde etkilediği sonucu çıkarılabilir. Cari açık değişkenine verilen pozitif bir şoka değişkenin kendisi onuncu dönemin sonuna kadar azalarak da olsa pozitif yönde tepki vermiştir. Bütçe açı̆̆ 1 (BAC) değişkeni ise verilen şoka iki dönem boyunca negatif daha sonra altıncı döneme kadar pozitif yönde tepki vermiş ve sonra şokun etkisi anlamlılığını yitirmiştir. Buradan kısa dönemde cari açıtaki pozitif bir etkinin bütçe açığını azalttığını ancak uzun dönemde ise cari açığın bütçe açığını artırdığı sonucu çıkarılabilir. Tasarruf-yatırım (TYAC) değişkeni, verilen şoka ikinci döneme kadar pozitif, daha sonra az da olsa altıncı döneme kadar negatif yönde tepki vermiştir. Buradan da cari açı̆̆ın kısa dönemde tasarruf-yatırım açığını artırdığı, uzun dönemde ise cari açığın az da olsa tasarruf-yatırım açığını azalttığı sonucu çıkarılabilir.

Response to Cholesky One S.D. Innovations \pm 2 S.E.

Response of BUYUME to D(TYAC)

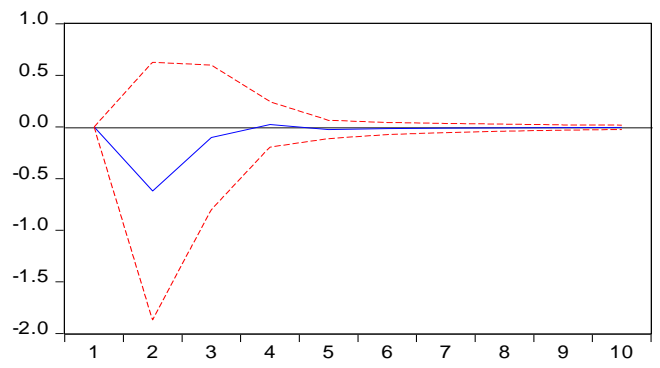

Response of CAC to D(TYAC)

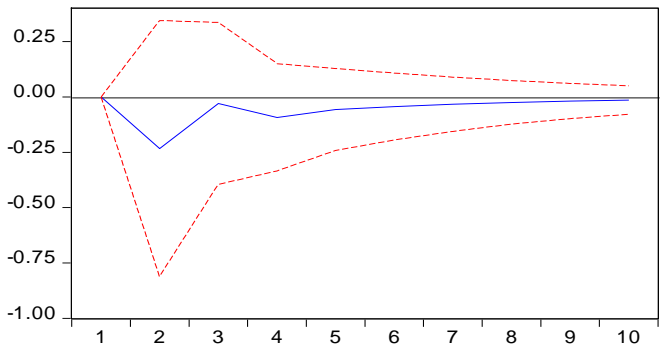

Şekil 4: TYAC Değişkenine Verilen Şoka Değişkenlerin Tepkisi
Response of $D(B A C)$ to $D(T Y A C)$

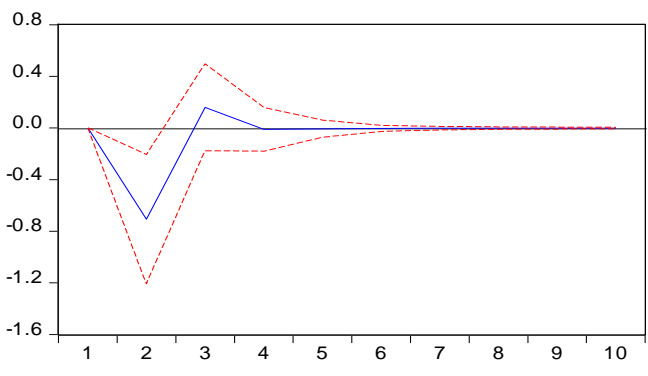

Response of D(TYAC) to D(TYAC)

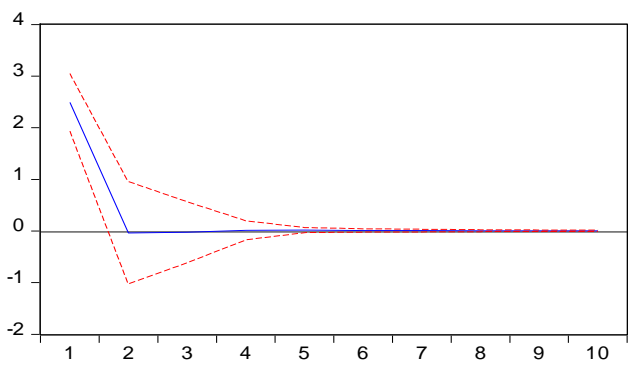

Tasarruf-yatırım (TYAC) değişkenine verilen pozitif bir şok karşısında, ekonomik büyüme (BUYUME) değişkeni üçüncü dönemin sonuna kadar negatif yönde tepki vermiş ve sonra şokun etkisi anlamlılığını yitirmiştir. Buradan kısa dönemde tasarruf-yatırım açığının ekonomik büyümeyi olumsuz yönde etkilediği sonucu çıkarılabilir. Tasarruf-yatırım açı̆̆ına verilen pozitif bir şoka değişkenin kendisi iki dönem boyunca pozitif yönde tepki vermiş ve sonra şokun etkisi anlamlılı̆̆ını yitirmiştir. Cari açık (CAC) değişkeni ise verilen şoka

\section{6}


ilk iki dönem daha fazla olmakla birlikte onuncu dönemin sonuna kadar negatif yönde tepki vermiştir. Buradan tasarruf-yatırım açığı ile cari açık arasında incelenen dönemde ters yönlü bir ilişki olduğu yani tasarruf-yatırım açığında meydana gelebilecek pozitif bir etkinin cari açı̆̆ı negatif yönde etkilediği sonucu çıkarılabilir. Son olarak bütçe açığı (BAC) değişkeninin, tasarrufyatırım açığı değiş̧kenine verilen pozitif şok karşısında, üç dönem boyunca negatif daha sonra dördüncü dönemde pozitif tepki vermiş ve şokun etkisi anlamlılığını yitirmiştir. Buradan da tasarruf-yatırım açığının kısa dönemde bütçe açıklarını azaltmakla birlikte bu durumun kısa sürdüğü ve daha sonra bütçe açığının arttığı sonucu çıkarılabilir.

Etki tepki analizinden sonra, bir değişkende yaşanan bir şokun ne kadarlık kısmının diğer değişkenlerden kaynaklandığını yüzdelik olarak gösteren varyans ayrıştırması yönteminden yararlanılabilir. Buna göre VAR modeline ilişkin varyans ayrıştırması tablo sonuçları şöyledir:

Tablo 7: BUYUME ve BAC Değişkenleri İçin Varyans Ayrıştırma Tablosu

\begin{tabular}{ccccccccc}
\hline & \multicolumn{9}{c}{ BUYUME } \\
\cline { 2 - 9 } möne & BUYUM & D(BA & CA & D(TYA & BUYUM & D(BA & CA & D(TYA \\
m & E & C) & C & C) & E & C) & C & C \\
\hline 1 & 100.00 & 0.00 & 0.00 & 0.00 & 20.64 & 79.35 & 0.00 & 0.00 \\
\hline 2 & 96.85 & 1.23 & 0.01 & 1.88 & 16.94 & 65.00 & 4.09 & 13.95 \\
\hline 3 & 96.49 & 1.32 & 0.25 & 1.92 & 17.00 & 63.81 & 4.86 & 14.31 \\
\hline 4 & 96.21 & 1.36 & 0.50 & 1.92 & 17.00 & 63.78 & 4.89 & 14.31 \\
\hline 5 & 96.10 & 1.37 & 0.59 & 1.92 & 17.00 & 63.76 & 4.91 & 14.31 \\
\hline 6 & 96.04 & 1.37 & 0.65 & 1.92 & 17.00 & 63.75 & 4.93 & 14.31 \\
\hline 7 & 96.01 & 1.38 & 0.68 & 1.92 & 16.99 & 63.75 & 4.93 & 14.30 \\
\hline 8 & 95.98 & 1.38 & 0.70 & 1.92 & 16.99 & 63.75 & 4.94 & 14.30 \\
\hline 9 & 95.97 & 1.38 & 0.71 & 1.92 & 16.99 & 63.74 & 4.94 & 14.30 \\
\hline 10 & 95.97 & 1.38 & 0.71 & 1.92 & 16.99 & 63.74 & 4.94 & 14.30 \\
\hline
\end{tabular}

Tablo sonuçları incelendiğinde; 1. dönemde ekonomik büyümedeki değişimin \%100'ünün kendisinden kaynaklandığ 1 görülmekte ve bu durum 10. Dönemin sonuna kadar büyük ölçüde devam etmektedir. Bütçe açığı değiş̧kenindeki değişimin ise 1 . dönemde $\% 79.35$ 'inin kendisinden geri kalan \% 20.64'ünün ise ekonomik büyüme şoklarından kaynaklandığı görülmektedir. $\mathrm{Bu}$ durum 10. Döneme gelindiğinde bütçe açığındaki değiş̧imin \% 63.74'ünün kendisinden, \% 16.99'luk kısmının ekonomik büyüme şoklarından, \%4.94'ünün cari açık şoklarından ve \% 14.30'luk kısmının ise tasarruf-yatırım açığı şoklarından kaynaklandığı görülmektedir.

Tablo 8: CAC ve TYAC Değişkenleri İçin Varyans Ayrıştırma Tablosu

\begin{tabular}{ccccccccc}
\hline & \multicolumn{4}{c}{ CAC } & \multicolumn{4}{c}{ D(TYAC) } \\
\cline { 2 - 8 } Dönem & BUYUME & D(BAC) & CAC & D(TYAC) & BUYUME & D(BAC) & CAC & D(TYAC) \\
\hline 1 & 45.54 & 0.20 & 54.25 & 0.00 & 17.78 & 14.27 & 18.94 & 48.99 \\
\hline
\end{tabular}


KAÜiiBFD 9(18), 2018: 501-522

\begin{tabular}{lllllllll}
\hline 2 & 36.99 & 4.14 & 57.85 & 0.99 & 19.06 & 14.05 & 19.07 & 47.80 \\
\hline 3 & 33.24 & 5.01 & 60.85 & 0.88 & 19.01 & 14.08 & 19.24 & 47.65 \\
\hline 4 & 31.69 & 5.34 & 61.99 & 0.96 & 18.99 & 14.08 & 19.32 & 47.60 \\
\hline 5 & 30.87 & 5.52 & 62.61 & 0.98 & 18.98 & 14.08 & 19.35 & 47.57 \\
\hline 6 & 30.42 & 5.63 & 62.94 & 0.99 & 18.98 & 14.07 & 19.38 & 47.55 \\
\hline 7 & 30.18 & 5.68 & 63.12 & 1.00 & 18.97 & 14.07 & 19.39 & 47.54 \\
\hline 8 & 30.04 & 5.71 & 63.23 & 1.00 & 18.97 & 14.07 & 19.40 & 47.54 \\
\hline 9 & 29.96 & 5.73 & 63.28 & 1.00 & 18.97 & 14.07 & 19.40 & 47.54 \\
\hline 10 & 29.92 & 5.74 & 63.32 & 1.00 & 18.97 & 14.07 & 19.40 & 47.53 \\
\hline
\end{tabular}

Tablo sonuçları incelendiğinde; 1 . dönemde cari açıtaki değişimin \% 54.25'lik kısmının kendisinden kaynaklandığı, \% 45.54'lük kısmının ise ekonomik büyüme şoklarından kaynaklandığı görülmektedir. Bu durum 10 . döneme gelindiğinde cari açıktaki değişimin \%63.32'lik kısmının kendisinden, \% 29.92'lik kısmının ekonomik büyüme şoklarından, \%5.74'lük kısmının bütçe açığ kaynaklandığı görülmektedir. Tasarruf-yatırım açığı değişkenindeki değişimin ise 1. dönemde \% 48.99'luk kısmının kendisinden, \% 17.78'lik kısmının ekonomik büyüme şoklarından, \% 14.27'lik kısmının bütçe açığı şoklarından ve \% 18.94'lük kısmının da cari açık şoklarından kaynaklandığı görülmektedir. $\mathrm{Bu}$ durum 10. döneme gelindiğinde tasarruf-yatırım açığındaki değişimin \% 47.53'lük kısmının kendisinden, \% 18.97'lik kısmının ekonomik büyüme şoklarından, \% 14.07'lik kısmının bütçe açığı şoklarından ve \% 19.40'l1k kısmının da cari açık şoklarından kaynaklandığı görülmektedir.

Çalışmanın bu kısmında modele ilişkin yapılan analizlerin sonuçlarının güvenilirliği açısından modelin hata terimiyle ilgili testlerin yapılması gerekmektedir. Bu nedenle modelde otokorelasyon ve değișen varyans sorunu olup olmadığını belirleyebilmek amacıyla Otokorelasyon-LM ile White Değişen varyans testleri yapılacaktır. Yapılan bu testlere ilişkin sonuçlar aşağıda tablo 9'da verilmiştir.

Tablo 9: Otokorelasyon-LM Testi ve White Değişen Varyans Testi Sonuçları

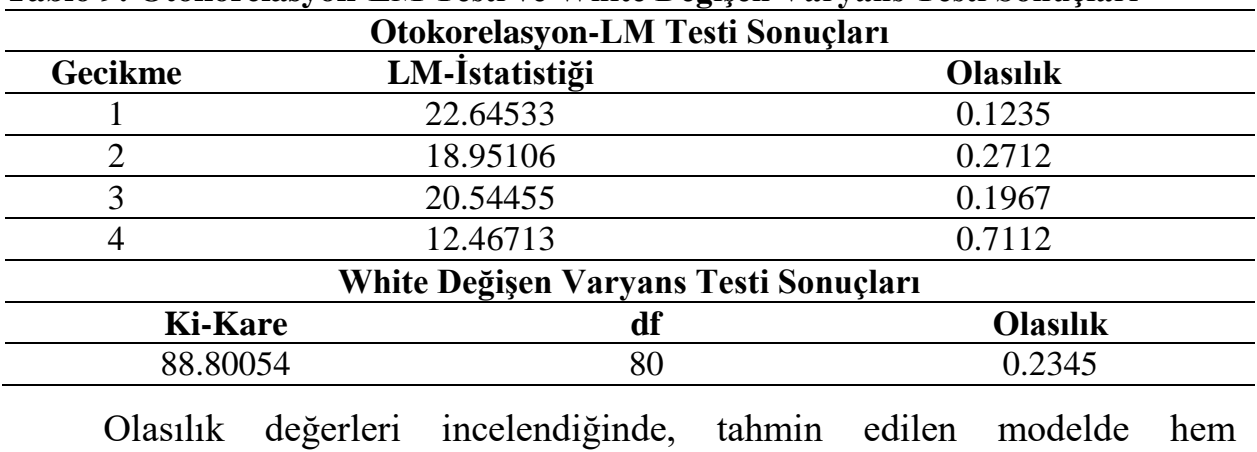

\section{8}


KAÜIiBFD 9(18), 2018: 501-522

otokorelasyon hem de değişen varyans sorununun olmadığı görülmektedir.

\section{SONUÇ}

$\mathrm{Bu}$ çalışmada ekonomik büyüme, bütçe açığı, cari açık ve tasarruf-yatırım açığı arasındaki ilişki Vektör Otoregresif (VAR) analizi ile araştırılmıştır. Türkiye için 1975-2016 dönemlerini kapsayan çalışmada yıllık zaman serileri kullanılarak VAR modeli kurulmuştur. Çalışmada VAR modeline geçilmeden önce modelde yer alan tüm değişkenler birim kök testleriyle sınanmış ve düzeyde durağan olmayan bütçe açığı (BAC) ve tasarruf-yatırım açığı (TYAC) değişkenlerinin farkları alındıktan sonra durağan hale geldiği görülmüştür. Çalışmanın bu kısmından sonra VAR analizinde kurulan model için uygun gecikme seviyesi belirlenerek VAR analizi ve beraberinde etki-tepki analizi ile varyans ayrıştırması yapılmıştır.

Yapılan analizler sonucunda, bütçe açıklarının kısa dönemde ekonomik büyüme üzerinde pozitif bir etkisi olduğu görülmekle birlikte uzun dönemde ekonomik büyümeyi olumsuz etkilediği görülmüsstür. Bu durum Türkiye'de ekonominin canlandırılması için yapılan genişletici maliye politikalarının kısa dönemde olumlu sonuçlar vermesine rağmen artan kamu harcamalarının finansmanının sağlanmasında karşılaşılan zorluklardan dolayı uzun dönemde ekonomide daralmaya neden olacağını göstermektedir.

Analiz sonuçlarında cari açığın kısa dönemde az da olsa ekonomik büyümeyi olumsuz olarak etkilediği ancak uzun dönemde ekonomik büyümede olumlu etkisinin olduğu görülmektedir. Bu durum cari açıkla, bütçe açığının ekonomik büyümeyi gerek kısa dönemde gerekse uzun dönemde birbirlerinin tersi yönde etkilediği sonucunu vermektedir. Her ne kadar analiz sonuçlarında cari açığın uzun dönemde ekonomik büyüme üzerinde olumlu etkisi görülmüş olsa da, bir ülkenin sürekli olarak cari açık vermesi o ülkede önemli ölçüde döviz sıkıntısının yaşanmasına neden olacak ve bu da beraberinde ekonomideki diğer önemli parametreler üzerinde olumsuz etkiler doğuracaktır. Ayrıca cari açığın süreklilik kazanması ülkenin ödemeler bilançosunun da açık vermesine neden olacaktır. $\mathrm{Bu}$ nedenle Türkiye'nin ekonomik büyümeyi sürekli hale getirebilmesi için özellikle teknoloji yoğun mallara olan yatırımlarını artırarak katma değeri yüksek olan malları üretmeli ve de dış ticaret politikalarını bu tür malların üretimi ve satışına göre belirlemelidir.

Son olarak analiz sonuçlarında tasarruf-yatırım açığının ekonomik büyümeyi olumsuz yönde etkilediği görülmektedir. Bu durum özel sektör yatırımlarının tamamen özel kesim tasarruflarıla finanse edilmemesi sonucunda ortaya çıkan açığın karşılanabilmesi için yatırımların finansmanının borçlanarak sağlandığı ve artan borçlanmanın da ekonomik büyümeyi iktisadi beklentilere uygun olarak olumsuz etkilediğini göstermektedir. Bu nedenle 
ulusal tasarrufların artırılması ve yatırımların finansmanının ulusal tasarruflarla karşılanabilmesi için gerekli politikaların en kısa sürede yapılması gerekmektedir.

\section{KAYNAKÇA}

Afonso, A. \& Rault, C. (2009). Budgetary and external 1mbalances relationship: A panel data diagnostic. Cesifo Working Paper, 2559, 1-38.

Akbaş, Y. E., Lebe, F. \& Zeren, F. (2014). Testing the validity of the triplet deficit hypothesis for Turkey: Asymmetric causality analysis. Journal of Business and Economics, 7(14), 137-154.

Altun, N. \& İnce, N. (2014). Türkiye'de üçüz açıklara ampirik bir yaklaşım: 1975-2010. Sakarya Íktisat Dergisi, 3(2), 40-61.

Azapoğlu, M. \& Direkçi, T. B. (2015). İkiz açıklar hipotezi: Türkiye uygulaması 19982013. Journal of Academic Researches and Studies, 7(12), 74-89.

Baharumshah, A. Z. \& Lau, E. (2009). Structural breaks and the twin deficits hypothesis: Evidence from East Asian countries. Economic Bulletin, 29(4), 25172524.

Bayrak, M. \& Esen, Ö. (2012). Bütçe açıklarının cari işlemler dengesi üzerine etkileri: İkiz açıklar hipotezinin Türkiye açısından değerlendirilmesi. Ekonomik Yaklaşım, 23(82), 23-49.

Berke, B., Temiz D. \& Karakurt, E. (2015). Üçüz açık ve büyüme ilişkisi: Türkiye örneği. Eskişehir Osmangazi Üniversitesi İ̈BF Dergisi, 10(2), 67-89.

Bolat, S., Belke, M. \& Aras, O. (2011). Türkiye'de ikiz açık hipotezinin geçerliliği: Sınır testi yaklaşımı. Maliye Dergisi, 161, 347-364.

Chowdhury, K. \& Saleh, A.S. (2007). Testing the keynesian proposition of twin deficits in the presence of trade liberalisation: Evidence from Sri Lanka. Economics Working Papers, 20(1), 3-33.

Çelik, S., Deniz, P. \& Seden, E. (2008). Eşbütünleşme analiziyle altı gelişmekte olan ülke için ikiz açılar hipotezi. 20 Ocak 2017 tarihinde http://debis.deu.edu.tr/userweb//iibf_kongre/dosyalar/scelik.pdf adresinden erişildi.

Daly, V. \& Siddiki, J.U. (2009). The twin deficits in OECD Countries: Cointegration analysis with regime shifts. Applied Economic Letters, 16(11), 1155-1164.

Dineri, E. \& Taş, İ. (2016). İkiz açık hipotezi: Türkiye'de teorik ve ampirik inceleme. Akademik Sosyal Araştırmalar Dergisi, 4(32), 372-390.

Erdinç, Z. (2008). İkiz açıklar hipotezinin Türkiye'de 1950-2005 yılları arasında eşbütünleşme analizi ve granger nedensellik testi ile incelenmesi. Anadolu Üniversitesi Sosyal Bilimler Dergisi, 8(1), 209-222.

Enders, W. (1995). Applied econometrics time series. Canada: John Wiles and Sons.

Feldstein, M. (1992). The budget and trade deficits aren't really twins. NBER Working Paper, 3966, 1-11.

Güder, F. \& Kılıç, C. (2016). Üçüz açık sorunu ve üçüz açık bileşenlerinin ekonomik büyüme üzerine etkisi: Türkiye örneği. Girişimcilik ve Kalkınma Dergisi, 11(2), 47-77.

\section{0}


Günaydın, İ. (2004). Bütçe ve ticaret açıkları arasındaki ilişki: Türkiye uygulaması. Ekonomik Yaklaşım, 15(52-53), 143-159.

Hakro, A. N. (2009). Twin deficits causality link-evidence from Pakistan. International Research Journal of Finance and Economics, 1(24), 54-70.

İpek, E. \& Kızılgöl, Ö. A. (2016). Türkiye ekonomisinde üçüz açık. Ege Akademik Bakış, 16(3), 425-442.

İyidoğan, P. V. \& Erkam, S. (2013). İkiz açıklar hipotezi: Türkiye için ampirik bir inceleme (1987-2005). Pamukkale Üniversitesi Sosyal Bilimler Enstitüsü Dergisi, 2013(15), 39-48.

Karanfil, M. \& Kılıç, C. (2015). Türkiye ekonomisinde üçüz açık hipotezinin geçerliliği: Zaman serisi analizi. International Journal of Management Economics and Business, 11(24), 1-20.

Kaufmann, S., Scharler, J. \& Winckler, G. (2002). The Austrian current acoount deficit: Driven by twin deficits or by intertemporary expenditure allocation. Empirical Economics, 27(3), 529-542.

Kılavuz, E. \& Dumrul, Y. (2012). İkiz açıklar hipotezinin geçerliliği: Teori ve uygulama. Atatürk Üniversitesi İktisadi ve İdari Bilimler Dergisi, 26(3-4), 239258.

Kim, S. \& Roubini, N. (2008). Twin deficit or twin divergence? Fiscal policy, current account and real exchange rate in the US. Journal of International Economics, 74(2), 362-383.

Kutlar, A. (2017). E.views ile uygulamalı çok denklemli zaman serileri. Kocaeli: Umuttepe Yayınları.

Mangır, F. (2012). Türkiye için ikiz açıklar hipotezi testi (1980- 2011). Niğde Üniversitesi İ̈BF Dergisi, 5(2), 136-149.

Marinheiro, C. F. (2008). Ricardian equivalence, twin deficits, and the feldsteinHorioka puzzle in Egypt. Journal of Policy Modeling, 30(6), 1041-1056.

Omoniyi, O.S., Olasunkanmi, O.I. \& Babatunde, O.A. (2012). Empirical analysis of Twins' deficits in Nigeria. IJMBS, 2(3), 38-41.

Özgen, F. B. \& Güloğlu, B. (2004). Türkiye'de iç borçların iktisadi etkilerinin VAR tekniğiyle analizi. ODTÜ Gelişme Dergisi, 31(1), 93-114.

Rahman, M., \& Mishra, B. (1992). Cointegration of US budget and current account deficits: Twins or strangers? Journal of Economics and Finance, 16(2), 119-127.

Salvatore, D. (2006). Twin deficits in the G-7 countries and global structural 1mbalances. Journal of Policy Modeling, 28(6), 701-712.

Shastri, S., Giri, A. K. \& Mohapatra, G. (2017). Assessing the triple deficit hypothesis for major South Asian countries: A Panel Data Analysis. International Journal of Economics and Financial Issues, 7(4), 292-299.

Szakolczai, G. (2006). The triple deficit of Hungary. Hungarian Statistical Review, 10, 40-62.

Şen, A., Şentürk, M., Sancar, C. \& Akbaş, Y. E. (2014). Empirical findings on triplet deficits hypothesis: The case of Turkey. Journal of Economic Cooperation and Development, 35(1), 81-102.

Şen, H. \& Kaya, A. (2016). Are the twin or triple deficits hypotheses applicable to postcommunist countries? BOFIT Discussion Papers, 2016(3), 4-41. 
Şengönül, A. (2008). Different twin deficits in different time intervals : evidence from Turkey. Asian African Journal of economics, 8(2), 139-152.

Tang, T. C. (2014). Fiscal deficit, trade deficit and financial account deficit: Triple deficit hypothesis with the U.S. experience. Monash University Discussion Paper, 6(14), 1-13.

Tülümce, S. Y. (2013). Türkiye'de üçüz açığın ampirik analizi (1984-2010). Maliye Dergisi, 2013(165), 97-114.

Türkay, H. (2013). Türkiye'de cari açık, bütçe açı̆̆ı ve yatırım-tasarruf açığı ilişkisi. Cumhuriyet Üniversitesi İktisadi ve İdari Bilimler Dergisi, 14(2), 253-269.

Üzümcü, A. \& Kanca, O. C. (2013). İkiz açık hipotezi: Türkiye üzerine bir uygulama (1980-2012). Inönü Üniversitesi Uluslararası Sosyal Bilimler Dergisi, 2(1), 17 42. 